\title{
Article
}

\section{Conversion of Agricultural Waste (Maize) into Energy using Biogas Technology}

\author{
Roksana Aftab Ruhi*1, Nusrat Jahan Methela ${ }^{1}$, Abul Khayer ${ }^{l}$, Fatiha Sultana Eti ${ }^{1}$, DR. Chayan Kumer Saha ${ }^{2}$ \\ ${ }^{1}$ Department of Agriculture, Noakhali Science and Technology University, Noakhali-3814, Bangladesh. \\ ${ }^{2}$ Department of Farm Power and Machinery, Bangladesh Agricultural University, Mymensingh, Bangladesh.
}

Corresponding Author: Roksana Aftab Ruhi, Department of Agriculture, Noakhali Science and

Technology University, Noakhali-3814, Bangladesh. Email: ruhi435@ outlook.com, +8801772616664

\begin{abstract}
The aim of the study was to examine the biogas and methane yield of maize silage, a wastes in agricultural point of view and compare it to the biogas productivity of commonly used mixture of maize silage and mixed fodder with water. The experimental study was carried out into 2 parts. Firstly, the batch experiment was conducted in Mesophilic conditions $\left(35^{\circ} \mathrm{C}\right)$, at five different hydraulic retention times (HRT): 6 DAT, 11 DAT 20 DAT 29 DAT and 41 DAT. The results revealed that maize silage was generated the highest biogas yield of $537 \mathrm{~mL} / 241 \mathrm{~mL}$ at the HRT of 6days /41 days. Mixed fodder produced the highest biogas yield of $421 \mathrm{~mL}$ at the HRT of 6th days and the lowest one was $252 \mathrm{~mL}$ at the HRT of 20th days. Finally, the methane, carbon dioxide and hydrogen sulphide of biogas produced from maize silage and mixed fodder were analyzed using a gas chromatography. The results shown that biogas from maize silage precedes the gas less than the mixed fodder. In the field level experiment proved that from mixed fodder produced gas which would be enough for 7 member's family used 3 months for the purpose of their cooking.
\end{abstract}

Keywords: Biogas; Agricultural Wastes; Maize Silage; Gas Production.

\section{Introduction}

Bangladesh is in the midst of a severe and worsening energy crisis, with a population of about 160 million living in an area of 147,570 km2.In Bangladesh, only 3\% of the population enjoys the facility of natural gas coming to their homes through pipelines. Despite her large population, Bangladesh is one of the less energy consuming countries with $257 \mathrm{KwH}$ per capita [1]. An agriculture based country like Bangladesh has huge potentials for utilizing biogas technologies. If each family of Bangladesh can be associated with a biogas plant, then only human excreta will give about 10 billion cubic $\mathrm{m} 3$ biogas [2]. Biogas is produced from anaerobic digestion and is considered a clean energy source for those who want an alternative energy pathway. Anaerobic digesters convert organic waste (waste water sludge, agricultural and food waste, animal and human manure) into energy (biogas). The composition of biogas varies depending upon the origin of the anaerobic digestion process, on type and chemical composition of substrates, technology used and operational parameters [3]. Various types of biodegradable organic waste from agriculture and industry may be used as a substrate for biogas formation [4]. Maize (Zea mays L.) is one of the agricultural plants that is suitable substrate for biogas production. Fresh as well as ensiled maize can be used as biogas substrate [5]. Maize silage is a substrate free of harmful organic substances and heavy metals, which are responsible for the inhibition of the methane fermentation [6]. In recent decades, along with the development of renewable energy, both grain (bioethanol) and silage (methane fermentation) have been used for bio-energetic purposes [7]. The goal of the combined cultivation is to improve the silage through the combined harvest of both crops, and simultaneously complement the nutrient inputs, which in turn generate higher specific methane yields and methane hectare yields. 


\section{Materials and Methods}

\subsection{Experimental site}

On the basis of this paper potentiality the research had been done in Subarna Char, Noakhali, Bangladesh from February, 2018 to August, 2018. Location of the site is $24^{\circ} 75^{\prime} \mathrm{N}$ latitude and $90^{\circ} 5^{\prime} \mathrm{E}$ longitude which fall under the AEZ 18 i.e. Young Meghna Estuarine Flood plain. The experimental site is indicated on the map of AEZ of Bangladesh. The weather is controlled by monsoon season and the soil is sandy loamy. The laboratory experiment was done at Green energy knowledge hub (Biogas) laboratory, Bangladesh Agicultural University, Mymensingh, Bangladesh (Fig 1).

\subsection{Substrates:}

The research material was maize and mixed fodder (maize silage and grass fodder). The soil for the proposed maize crops was ploughed in the late winter in 2018. The soil was tilted by a power tractor in February 2018. One maize hybrids "Hybrid Corn-984 Gold' and 'Hybrid Suit Jambu grass were sown in sandy loam soil on February 16, 2018. Fertilization of plants was provided by mineral fertilizers (Urea 35kg, TSP 20 kg, MP 15 kg, Gypsum 12 kg, Zinc 1kg, Boron $.5 \mathrm{~kg}$, Cow dung $300 \mathrm{~kg}$ ). The maize samples were harvested in '21-22 May, 2018. The maize samples was weighted and the average biomass DM yield was calculated in harvesting time. All samples of fresh maize were chopped in "3inch" pieces and filled in digester on 1st day, 4th day, at the 6th and 9th days the digester were filled. Amount of maize substrate filled in degester on 1 st day was $675 \mathrm{~kg}$, on 4 th day $75 \mathrm{~kg}$ maize substrate was added. Then after 5days (at the 6 th days) the digester were filled with maize silage and grass fodder together at $1425 \mathrm{~kg}(750 \mathrm{~kg}+575 \mathrm{~kg}$, respectively) and $1325 \mathrm{~kg}$ at the 9 th day.

\subsection{Methods used for producing Biogas}

In this research we used Anaerobic Digestion methods to produced biogas in china fixed dome plant. The biogas plant of daily gas production capacity of $150 \mathrm{ctt}$ (4.25 m3) has been used for the studies

\subsection{Experimental Procedure}

In this work the production of biogas from raw and digested agricultural wastes were used through semi batch and continuous digestion processes. Mixed fodder and Maize Silage chemical analysis was done in the Biogas laboratory in Bangladesh Agriculture University, Mymensingh, Bangladesh. The maize silage was stored 14 days for decomposition. In the laboratory experiment of the biogas production from the maize silage and mixed fodder done through the Batch type fermentation process. To start the experiment of each agricultural residue, 50-154 $\mathrm{ml}$ of inoculums were introduced in the anaerobic digester. Such an inoculum was anaerobically digested until it released all gas production. The digestion system was mixed for maintaining a contact between microorganisms and the substrate (Fig 3). It was finally sealed by a paraffin film. The anaerobic digestion system consists of 200L digester tank and 150L of storage tank. A quantity of biogas production was daily recorded until no biogas produced. Each experimental HRT was repeated 3 times to minimize an experimental uncertainty.

\subsection{Chemical Analysis of Substrates}

Muffle Furnace was used for determination of Ash content. Biogas 5000 gas analyser is used for the Biogas analysis. To know the raw and processed agricultural wastes studied in this work the biogas composition was analyzed using a mobile gas chromatography.

\subsection{Estimation of Dry Matter Content}


In the laboratory, during determination of dry matter content the following formula was used under oven dry condition at $1050 \mathrm{C}$ and kept for $24 \mathrm{hrs}$.

$\mathrm{DM}=$ Total Weight - Tray Weight

Here's,

Total Weight $=$ Tray Weight + Substrate Weight

After oven dry it was weighted and then put into the Ash container for Ash calculation.

\subsection{Estimation of the Volatile Solids}

The amount of residues left after the ignition of oven dried sample at $5750 \mathrm{C}$. To determine volatile solid and Ash analysis, oven dried moisture free sample were weighed and place at the muffle furnaces at $5750 \mathrm{C}$ for minimum $4 \mathrm{hrs}$. The dried samples were placed in smaller porcelain cup and the same procedure was followed. The porcelain cups were first weighed empty and then with the dried samples. Afterwards they were put in the oven at 550oC and then weighed again. The volatile solids were calculated using the following equation:

$\% V S=\frac{w_{c}-w i}{w d} \times 100$

Where,

Wc is the Cup and the dried sample weight and Wi is the cup and incinerated sample weight.

\subsection{Estimation of the Total Solids}

Total solids were determined by subtracting moisture from hundred percent. Loss of weight when ignited at $1050 \mathrm{C}$ was measure of total organic content of agro-wastes.

$$
\% T S=\frac{W t(\text { weight of petri dish with sample-Wt(weight of empty petridish) }}{W t(\text { weight of sample })} \times 100
$$

\subsection{Estimation of Moisture Content}

Moisture content of substrate was measured by loss of weight after drying at temperature 1050C for $5 \mathrm{hr}$. Moisture content using the following equation,

$$
\% M C=\frac{\text { weight of the sample-weight of sample after drying }}{\text { weight of sample }} \times 100
$$

\subsection{C: N Ratio Analysis}

In this research I was used NOVA 60 instrument that has all the cell tests pre-programmed. The device automatically recognized and measured the concentration of total Nitrogen and Ammonia.

\subsection{Statistical Analysis}

The collected data were subjected to Analysis of Variance (ANOVA) with CRD method to determine the significance of the effect of mixed fodder (silage and grass fodder) on the yield of biogas from maize at 95\% confidence level. 


\section{Results}

\subsection{Composition of Substrates}

The composition of maize substrate was found through the lab analysis and mixed fodder was collected as a Secondary data. Authors should discuss the results and how they can be interpreted in perspective of previous studies and of the working hypotheses. The findings and their implications should be discussed in the broadest context possible. Future research directions may also be highlighted. In Table 1 and Figure 4, maize silage has comparatively higher volatile solids content, expected to produce the highest amount of biogas. Since the maize contains a significant amount of polysaccharides and proteins and their hydrolysis and acidification separate from the methanogenic phase can accelerate anaerobic degradation. In the mixed fodder oil contents, crude proteins, dry matter content and the water portion are approximately higher than the single silage experiment.

\subsection{Chemical Composition of Produced Gas}

According to the Fig 6 and Table 2, at the 6th day the percentage of Methane of Mixed substrates were much higher than the silage in individuals but the amount of Hydrogen Sulfide was less in mixed fodder as same as the data showed in Fig 7, which represented the 11th days production. According to the table 4 at the 20th days the percentage of Methane of mixed substrates was less than the silage in individual but the amount of Hydrogen Sulphide was high than the mixed one (Table 2). In Table no 3 showed the composition of the substrates at 29th days where the percentage of Methane of mixed substrates was high than the silage in individual. The compound of carbon dioxide was less as compared to the mixed one except the amount of the Hydrogen Sulphide. In Table no 6 showed the composition of the substrates at $41 \mathrm{t} \mathrm{h}$ days. According to the table the percentage of Methane of Mixed substrate was much similar to the silage in individuals. The other compound was almost equal as compared to each one except the amount of the Hydrogen Sulphide. The amound of Hydrogen Sulphide was high in Silage than the mixed substrate.

\subsection{Carbon Nitrogen Ratio}

The results show that carbon to nitrogen ratio affects the volume of the generated biogas. Maize silage was collected from studies, their carbon $(\mathrm{C}) /$ nitrogen $(\mathrm{N})$ ratios were determined. The results showed that applying chemical fertilizers (NPK) or chemical fertilizers increased the $\mathrm{N}$ content and decreased the $\mathrm{C} / \mathrm{N}$ ratio of maize silage (Table 3).

\section{Discussions}

The experimental results obtained in this work agree well with those reported by N. Aramrueang et al. who studied effects of hydraulic retention time and organic loading rate on performance and stability of anaerobic digestion of Spirulina platensis. Maize Silage can be burnt to produce heat, electricity or both [7]. Utilization of biogas would reduce the use of fossil fuel-derived energy and reduce environmental impact as well as demand for wood and charcoal for cooking [8]. The chemical 
composition of maize silage was typical for the substrate and was similar to the results of other studies [8]. The chemical analysis of volatile solids (VS), crude ash (CA) crude protein (CP) were conducted as described [9]. Briefly, VS, and CA were determined using a gravimetric method after drying at $105^{\circ} \mathrm{C}$ and $550{ }^{\circ} \mathrm{C}$, respectively. The contents of MC and $\mathrm{CP}$ were analysed by Kjeldahl's method. Organic matter composition in terms of non-recalcitrant Chemical Oxygen Demand (COD), crude protein, lipids/oils and carbohydrates has a strong influence on the biogas potential and $\mathrm{CH} 4$ yield [10]. There was a little fluctuation in gas production in every interval of days. The $\mathrm{C} / \mathrm{N}$ ration of grass was $27: 1$, which is optimum in compare to the standard values (20:1 to 30:1)). But the C/N ratio of maize is "24.2:1". The value of $\mathrm{C} / \mathrm{N}$ ratio reported by other investigators is also around 24.2 [11]. If carbon nitrogen ration in the substrate may be kept between 20:1 to 30:1 then we get high rate of biogas production. When the $\mathrm{C}: \mathrm{N}$ ratio is too wide, carbon cannot optimally be converted to $\mathrm{CH} 4$ and the $\mathrm{CH} 4$ production potential is not fully achieved [11].

\section{Conclusions}

In the study the agricultural wastes samples, maize silage and mixed fodder has bio-energy potential and found to be suitable feed stock for biogas production at laboratory scale as well as at the field experiment. In this work a brief review of biogas production technologies and a characteristics of selected agricultural substrates and their potential for biogas production was made. In the long period of the digestion the carbon dioxide yield is increased enough at the maize silage treatment and in case of Hydrogen Sulfide amount is increased enough at the mixed fodder treatment which provides the continuous gas production in the experiment. In conclusion, it can be stated that the anaerobic digestion of maize silage and mixed fodder seems to be an attractive method for agricultural waste utilization and energy generation if the proportions of these substrates are properly selected.

Author Contributions: "Roksana Aftab Ruhi contributed on conceptualization, methodology, software, validation, formal analysis, investigation, resources, data curation, writing-original draft preparation. Abul Khayer and fatiha Sultana Eti have contribution on writing - review and editing, Nusrat Jahan Methela and DR. Chayan Kumer Saha contributed on visualization, supervision, project administration.

Funding: "This research received no external funding"

Conflicts of Interest: “The authors declare no conflict of interest." 
Appendix A

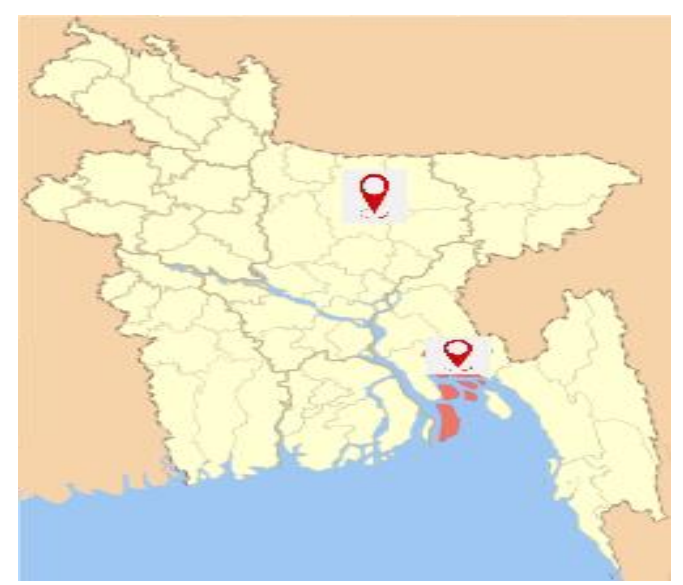

Fig A1: Experimental Sites with GPS icon

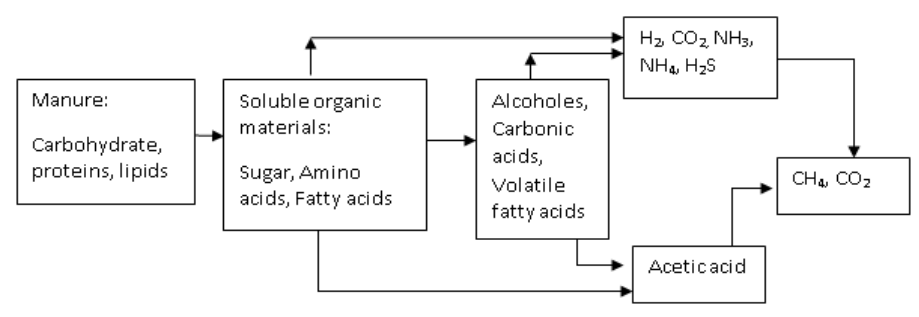

Figure A2: Schematic diagram of anaerobic digestion
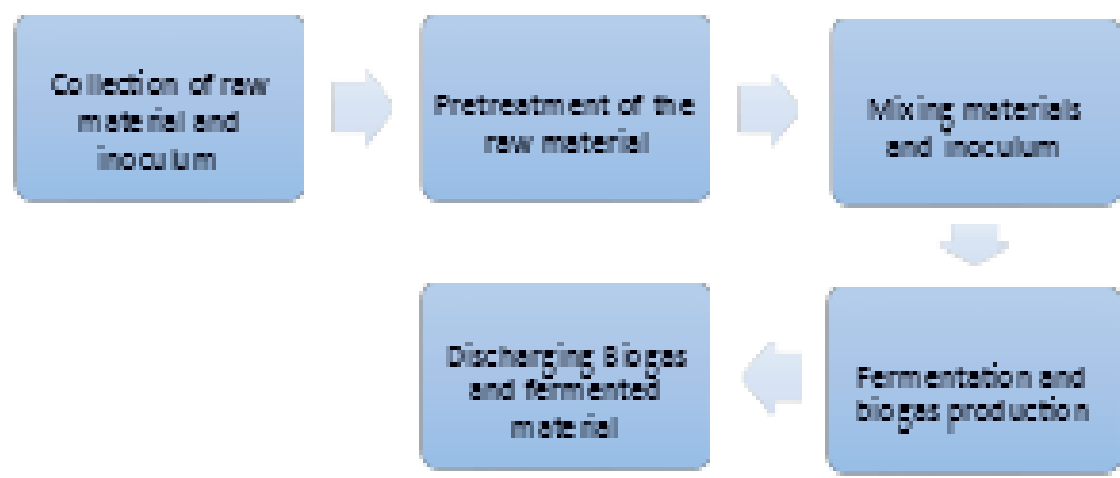

Figure A3: Batch type process set up in the laboratory at Green Energy Knowledge Hub (GEKH), Bangladesh Agricultural University, Mymensingh 
Table A1: Composition of Substrates

\begin{tabular}{|c|c|c|c|c|c|c|c|}
\hline Substrate & $\begin{array}{l}\text { Oil } \\
(\%)\end{array}$ & $\begin{array}{l}\text { Crude } \\
\text { Proteins } \\
\text { (\%DM) }\end{array}$ & $\begin{array}{l}\text { Moisture } \\
\text { content } \\
(\%)\end{array}$ & $\begin{array}{l}\text { Dry } \\
\text { Matter } \\
\text { Content } \\
\text { (g) }\end{array}$ & $\begin{array}{l}\text { Ash } \\
\text { Content } \\
\text { (g) }\end{array}$ & $\begin{array}{l}\text { Water } \\
\text { Portion } \\
(\%)\end{array}$ & $\begin{array}{l}\text { VS } \\
\text { (Volatile } \\
\text { Solids) } \\
(\%)\end{array}$ \\
\hline $\begin{array}{l}\text { Maize } \\
\text { Silage }\end{array}$ & 2.86 & 10.86 & 94 & 9.45 & 5.94 & 18 & 95 \\
\hline $\begin{array}{l}\text { Mixed } \\
\text { Fodder }\end{array}$ & 3.34 & 10.90 & 76 & 11.6 & 4.02 & 37.3 & 72.6 \\
\hline
\end{tabular}

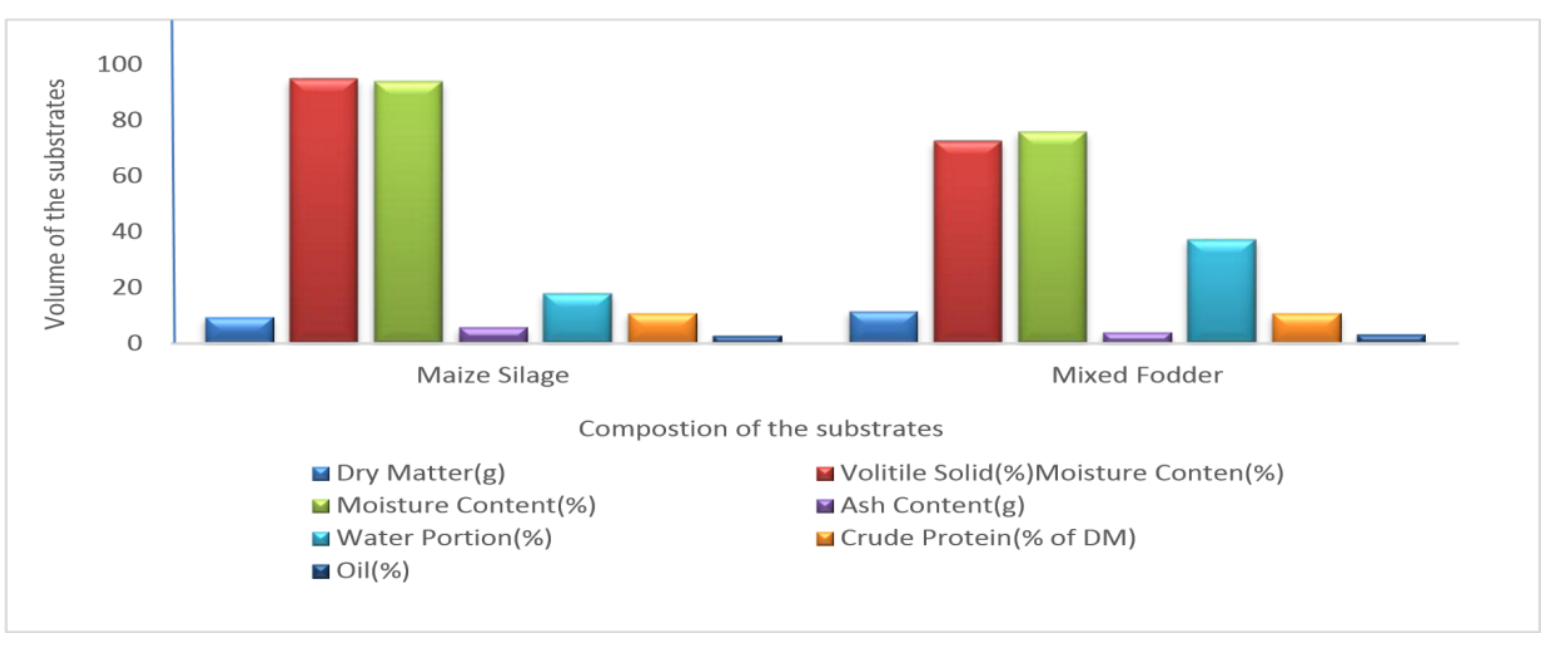

Figure A4: Comparison of the Substrates Chemical Compounds 


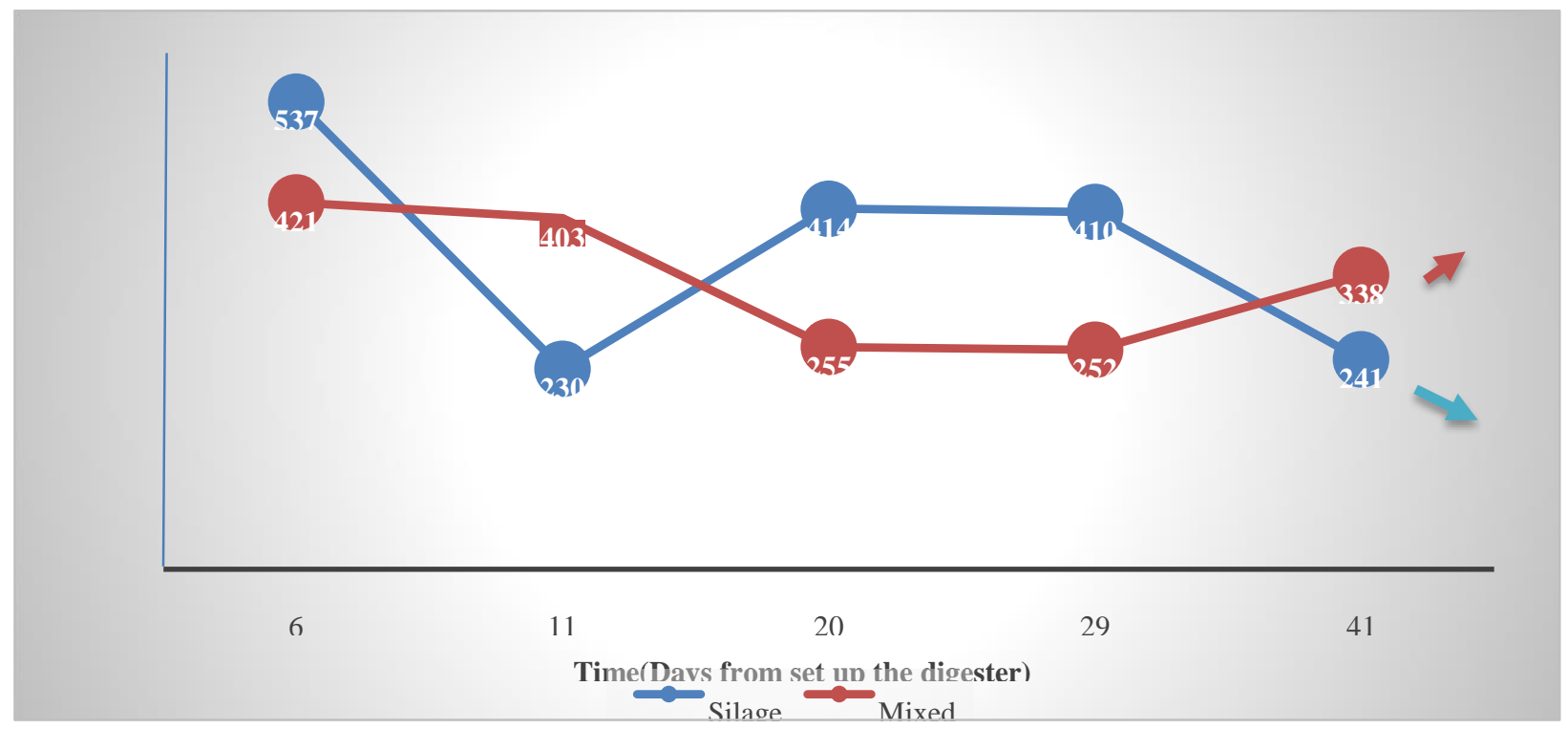

Figure A5: Daily Biogas Production in the Laboratory Experiment

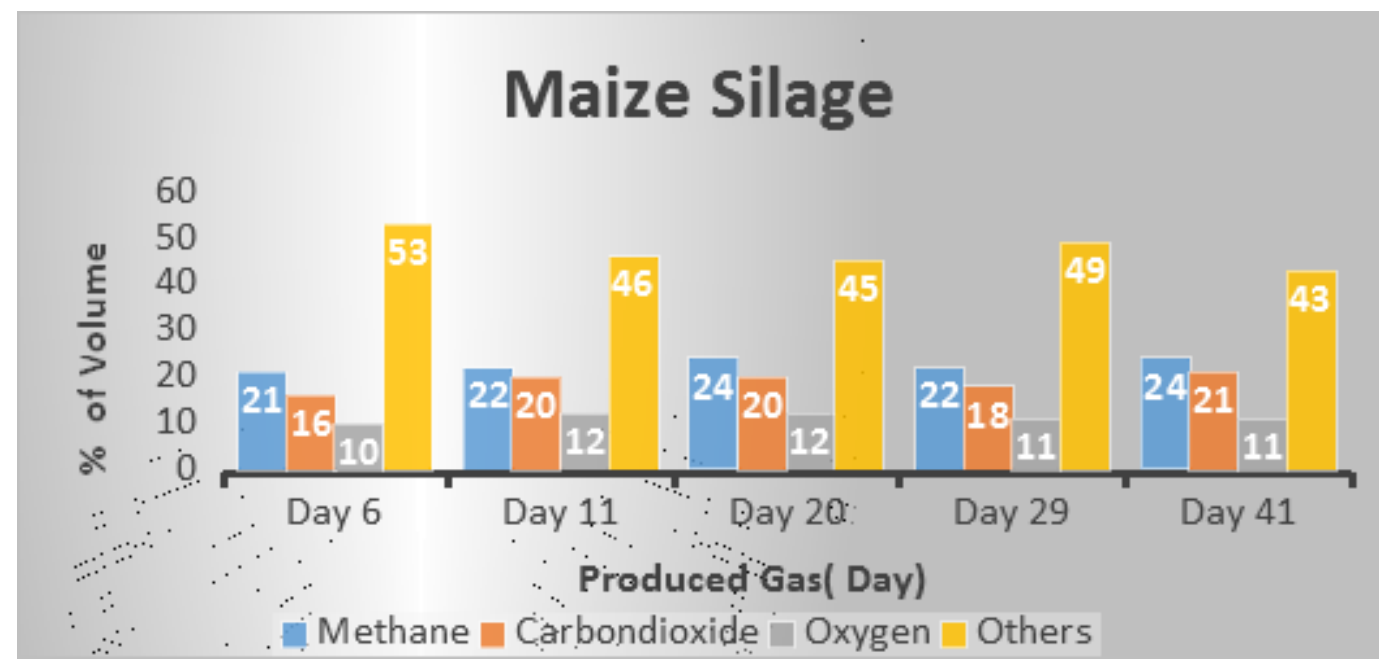

Figure A6: Produced Gas Composition from Maize Silage (6th Day-41th Day) 


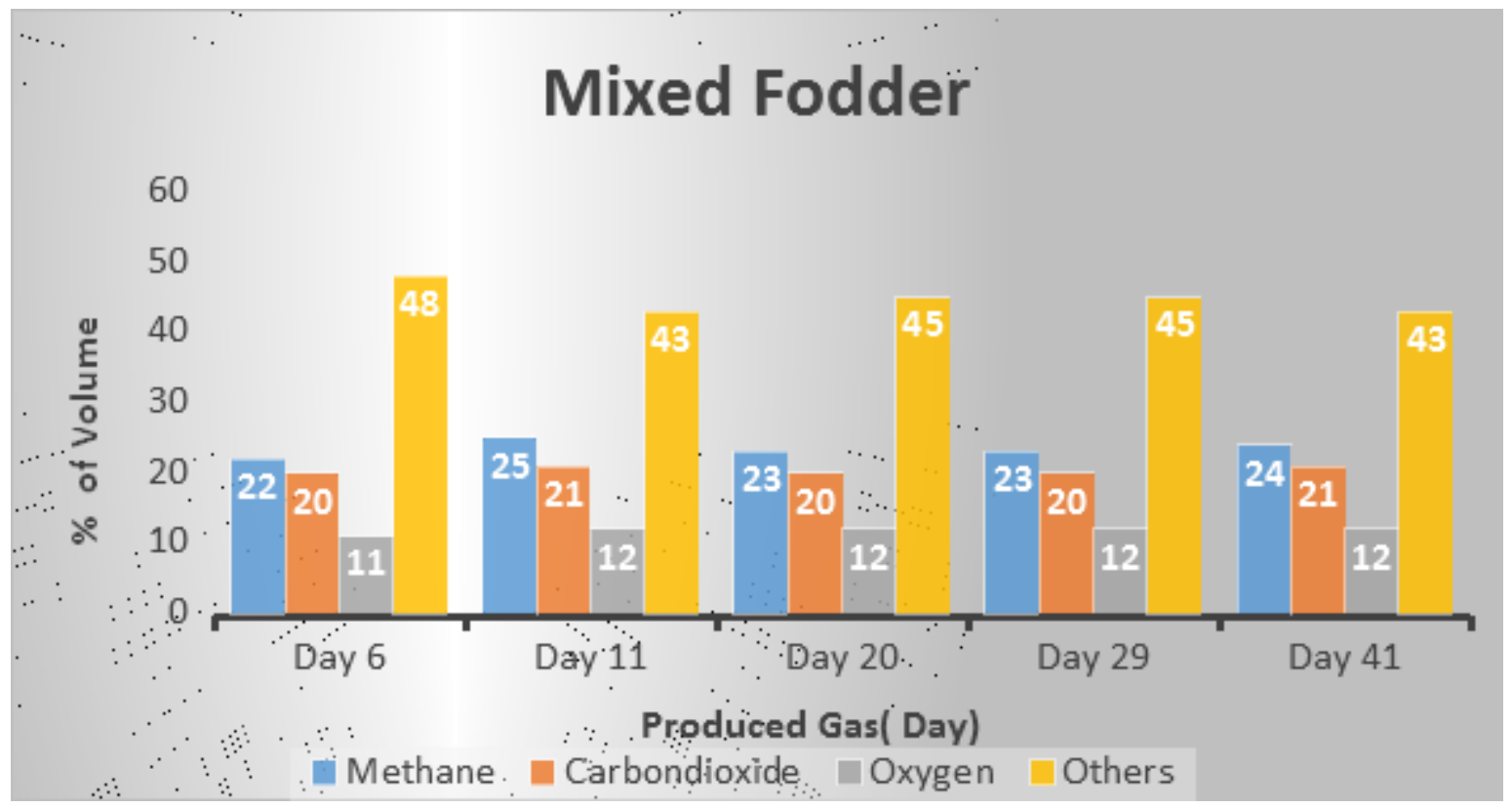

Figure A7: Produced Gas Composition from Mixed Fodder (6th Day-41th Day)

Table A2: Chemical Composition of biogas produced from Maize Silage

\begin{tabular}{|c|c|c|c|c|c|}
\hline Days & $\begin{array}{c}\text { Chemical } \\
\text { Name }\end{array}$ & Silage & Cob & Mixing & Inoculum \\
\hline 6 DAT & & $13 p p m$ & $2 p p m$ & $4 p p m$ & $32 \mathrm{ppm}$ \\
\hline 11 DAT & & $20 \mathrm{ppm}$ & $2 \mathrm{ppm}$ & $6 \mathrm{ppm}$ & $15 \mathrm{ppm}$ \\
\hline $20 \mathrm{DAT}$ & $\mathrm{H}_{2} \mathrm{~S}$ & $26 \mathrm{ppm}$ & $4 \mathrm{ppm}$ & $20 \mathrm{ppm}$ & $18 \mathrm{ppm}$ \\
\hline $29 \mathrm{DAT}$ & & $22 \mathrm{ppm}$ & $3 \mathrm{ppm}$ & $11 \mathrm{ppm}$ & $21 \mathrm{ppm}$ \\
\hline $41 \mathrm{DAT}$ & & $25 \mathrm{ppm}$ & $12 \mathrm{ppm}$ & $22 \mathrm{ppm}$ & $28 \mathrm{ppm}$ \\
\hline
\end{tabular}

Table A3: C: $\mathrm{N}$ ratio of the substrates

\begin{tabular}{|l||l|}
\hline Substrates & Ratio of Carbon and Nitrogen \\
\hline Maize Residue & $24.2: 1$ \\
\hline Mixed Fodder & $27: 1$ \\
\hline
\end{tabular}




\section{References}

1. Achinas, S.; and Euverink, G.J.W. Theoretical analysis of biogas potential prediction from agricultural waste. Resource-Efficient Technologies 2016, 2(3), 143-147

2. Amon, T.; Kryvoruchko, V.; Amon, B.; Bodiroza, V.; Zollitsch, W.; Boxberger, J. Biogas production from energy maize. Landtechnik 2006, 51(2),56-68

3. Bartuševics, J.; Gaile, Z. Effect of silaging on chemical composition of maize substrate for biogas production. Landtechnik 2010, 61(2),86-118

4. Chandratre Sangita J.; Chaudhari V. K.; Bhushan. M.; Bavaskar K, P. Biogas Production from Local Agricultural waste by using Laboratory Scale Digester. Iranica Journal of Energy and Environment 2006, 12(1),304-316.

5. Chy, S.M. Study and review of biogas experience in Bangladesh and other countries (Doctoral dissertation, University of Dhaka) 2016.

6. Fadairo, A. A.; Fagbenle, R.O.; Biogas production from water Hyacinth blends. Journal of Agricultural Sciences 2014, 2(2), 45-60.

7. Islam, A.S.; Islam, M. “ISESCO-Science and Technology Vision". Journal of Environmental Sciences 2005, 4(2), 32-49.

8. Kabir, H.; Palash, M.S.; Bauer, S.; Appraisal of domestic biogas plants in Bangladesh. Bangladesh Journal of Agricultural Economics 2012, 35, (1-12)

9. Mia, M.A.S.; Nur-E-Alam, M.; Huque, S.; Rahman, M.M.; Ratnaweera, H. Biogas production through anaerobic digestion of tannery solid waste. Iranica Journal of Energy and Environment, 2017, 8(3):210-215

10. Oleszek, M.; Krzemińska, I. Enhancement of biogas production by co-digestion of maize silage with common goldenrod rich in biologically active compounds. Bio Resources 2016 12(1):704-714.

11. Smurzyńska, A.; Dach, J.; Kozłowski, K.; Mazurkiewicz, J.; Woźniak, E.; Boniecki, P.; Kupryaniuk, K.; Janczak, D.; Brzoski, M. Relevant biogas substrate-maize silage vs slaughterhouse waste. Indian Journal of agriculture 2017, 12(1), 37-50. 